\title{
Dynamická místa kurikula jako most mezi formálním a neformálním vzděláváním
}

\author{
Markéta Kuberská, Pavel Masopust, Lucie Kolářová, \\ Petr Desenský, Jan Slavík, Pavel Mentlík
}

\begin{abstract}
Abstrakt: Cílem této teoreticko-metodologické studie je vymezit didaktický konstrukt dynamická mista kurikula, zasadit ho do širšiho teoretického rámce, charakterizovat s nim spojené metody výzkumu a uvést príklady dobré praxe. Vúvodni ćásti príspèvku definujeme pojem dynamická mista a zasazujeme jej do kontextu etablovaných konstruktu jako je obsahová transformace nebo modernizace kurikula. V této ćásti studie také diskutujeme roli formálního a neformálního vzdèláváni prì rèseni dynamických mist kurikula. Dalši část príspèvku je zamèrena metodologicky a věnuje se rüzným zpưsobuim vymezováni dynamických mist oborù a jejich výbèru a legitimizace pro následnou transformaci. Posledni část se vènuje príkladuim dobré praxe. Představujeme zde dva návrhy řešeni zjištèných dynamických mist z kurikula fyziky a zemépisu pro ZŠ. Konstrukt dynamických mist je platný také pro kurikulum střednich škol. V textu nicménè klademe di̊raz predevšim na implementaci dynamických mist do kurikula základnich škol, které se dotýká v̌̌ech žákü. Dynamická mista kurikula v tomto textu predstavujeme jako potenciálni spojnici mezi formálnim a neformálnim vzdělávánim. Prvnim divvodem je, že pri procesu vymezováni a výbèru dynamických mist se nabizi spolupráce zástupců formálního vzdèláváni (oborovi didaktici, učitelé z praxe) i vzdèláváni neformálního (pracovnici science center a dalšich institucí neformálního vzdèlávání). Druhým diovodem je vysoký potenciál institucí neformálního vzdèláváni pro ztvárnèni dynamických mist diky dobře vybaveným expozicím a laboratorim. Skrze výukové programy nabizené institucemi neformálního vzdèláváni školám tak mũže docházet $k$ aktualizaci kurikula formálního vzdèláváni.
\end{abstract}

Klíčová slova: dynamická mista oborí, dynamická mista kurikula, aktualizace kurikula, obsahová transformace, neformálni vzdèlávání, science centra.

\section{1. ÚvOd A CÍLE}

Otázce, jak transformovat obsah oborů směrem $\mathrm{k}$ výuce, je věnována $\mathrm{v}$ pedagogice i oborových didaktikách dlouhodobě značná pozornost, např́iklad v rámci teorie obsahové transformace či modelu didaktické rekonstrukce (Jelemenská, Sander \& Kattmann, 2003; Knecht, 2007; Kattmann, 2009; Janík, Maňák \& Knecht, 2009; Slavík et al., 2017). Dosud téměr neřešena však zůstává otázka, jak konkrétně 
výzkumně zachytit aktuální a dynamický vývoj v oborovém výzkumu a jeho následné zohlednění v kurikulu př́ślušných disciplín. Rovněž není dostatečně řešen potenciál významně se rozvíjejícího neformálního vzdělávání (často úzce provázaného s oborovým výzkumem) v této oblasti. Právě to zohledňuje námi prezentovaný konstrukt dynamických míst kurikula, který podchycuje výzkumně dosud neřešenou problematiku.

$\mathrm{V}$ úvodní části je pozornost věnována definování pojmu dynamická mista kurikula a teoretickému ukotvení konstruktu. Diskutována je rovněž role formálního a neformálního vzdělávání a jejich spolupráce při řešení problematiky dynamických míst. Další část studie se zabývá metodami vymezení dynamických míst oborů a jejich výběru pro následnou transformaci. Jsou zde představeny a diskutovány přístupy, které již byly $\mathrm{v}$ tomto směru realizovány. Jedná se např́iklad o zjištování dynamických míst oborů na základě analýzy počtu originálních publikací ve vědeckých časopisech na národní i mezinárodní úrovni, dotazování učitelů nebo expertní posouzení. $V$ poslední části jsou prezentovány dva návrhy řešení zjišstěných dynamických míst z kurikula fyziky a zeměpisu. $V$ prvním prípadě se jedná o téma „magnetická kapalina“, u něhož je demonstrováno provázání dynamických míst $\mathrm{s}$ dřive identifikovanými kritickými místy kurikula a tím i propojení formálního a neformálního vzdělávání. Druhým př́kladem je představení vzdělávacího programu na téma „moderní kartografie a GPS“.
Př́spěvek si klade cíle v několika rovinách:

- Definovat teoretický konstrukt dynamických mist kurikula a zasadit ho do širšího teoretického rámce.

- Definovat návaznost konstruktu na formální a neformální vzdělávání.

- Vymezit metody zjištování dynamických míst kurikula.

- Uvést konkrétní prríklady řešení dynamických míst ve spolupráci s institucemi neformálního vzdělávání.

\section{TeOretické uKotVEní \\ KONSTRUKTU „DYNAMICKÉ \\ MÍSTO KURIKULA“}

Konstrukt „dynamického místa kurikula“ vychází z prredpokladu, že určité oblasti vědních oborů prodělávají dynamický vývoj, tj. dochází v nich ke generování originálních vědeckých poznatků, které výrazně obohacují, aktualizují nebo dokonce mění paradigma daných oborů (Mentlík, 2016). Tyto oblasti vědních oborů lze označit za dynamická mista oborů (Mentlík, Slavík \& Coufalová, 2018).

Dalším důležitým východiskem je teorie obsahové transformace (Janík et al., 2009; Slavík et al. 2017; Janík, 2018), na jejímž základě vznikají procesem ontodidaktické transformace $\mathrm{z}$ oborových obsahů obsahy kurikulární. Ty jsou formálně zakotvené v klíčových kurikulárních dokumentech, což jsou státní a školní kurikulární programy (RVP, ŠVP) spolu $s$ učebnicemi, tematickými plány či učitelskými př́pravami na výuku (Hajerová 
Müllerová \& Slavík, 2020, s. 13-16). Dynamická místa kurikula tak lze definovat jako ty oblasti kurikula, které prošly ontodidaktickou transformací dynamických míst oborů. ${ }^{1}$

V první fázi procesu transformace (obr. 1) je vhodné identifikovat, ve kterých oblastech zkoumaného oboru dochází $\mathrm{k}$ dynamickému rozvoji. Metodám identifikování dynamických míst oborů je věnována samostatná kapitola (viz kap. 3). Po identifikování dynamických míst oborů dochází k výbèrua legitimizaci (viz fáze 2 na obr. 1). Výběr znamená definování oblastí oboru, které by se měly stát kurikulárním obsahem a proces legitimizace vede $\mathrm{k}$ odůvodnění jejich výběru (Janík et al., 2009). Oborové obsahy jsou v rámci ontodidaktické transformace obecně vybírány na základě celé řady kritérií (např. kritérium užitečnosti pro společnost nebo jedince, kulturní důležitosti, významu pro budoucnost apod.; Klafki, 1995). Proces výběru a legitimizace je důležitý i v př́padě transformace dynamických míst. V rámci současného výzkumu však existují dynamicky se rozvíjející oblasti oborů, které jsou často velmi úzce specializované, převážně teoretické a relevantní především jako základ pro další výzkum. Tato dynamická místa oborů ze své povahy nejsou zcela vhodná pro běžnou školní výuku. $\mathrm{Z}$ toho důvodu je potřeba jedno- značně definovat kritéria výběru a legitimizace dynamických míst pro ontodidaktickou transformaci. Kohout et al. (2019a, s. 9-10) navrhují pro př́pad fyziky aplikaci následujících kritérií, která by měla být splněna všechna současně: 1 . dynamická místa oboru jsou jednoznačně provázaná se stávajícím kurikulem na základní škole, 2. dynamická místa mají definovatelné a pro žáky představitelné dopady do běžného života, 3. dynamická místa lze demonstrovat pomocí názorných a pro žáky atraktivních pomůcek či modelů. S ohledem na to, že konstrukt dynamických míst pokládáme za nutné stavět odspoda tak, aby se alespoň v první fázi dotýkal primárně základních stavebních kamenů daného oboru, byla první z uvedených podmínek dále zpřesněna tak, aby dynamické místo mělo vazbu na to, co je řešeno typicky v prvních dvou letech výuky daného oboru na ŽS (tj. v zde demonstrovaných případech fyziky a zeměpisu v 6. a 7. ročníku).

Dynamická místa kurikula se při své realizaci ve vzdělávací praxi mohou za určitých podmínek stát misty kritický$m i$ (Rendl \& Vondrová, 2014; Mentlík et al., 2018), at již z hlediska žáků, učitelů, nebo podmínek učebního prostředí. Proto Kohout et al. (2019a) doporučují, aby se věnovala zvláštní pozornost jejich kritičnosti. Kritičnost dynamických míst může

\footnotetext{
${ }^{1}$ Z hlediska teorie obsahové transformace lze obsah oborů kultury a obsah kurikula shodně charakterizovat jako komplexní sémanticko-logickou strukturu, k níž se vážou instrumentální činnosti: kulturní praktiky (Slavík et al., 2017). Vybrané části sémanticko-logické struktury v kurikulu nebo v oboru nazýváme „místa“ (kritická místa, dynamická místa, klíčová místa) a charakterizujeme je př́vlastky, které poukazují na jejich zvláštní didaktické nároky spojené s přechody a návaznostmi mezi ontodidaktickou, psychodidaktickou a kognitivní transformací obsahu (srov. Janík, 2018).
} 


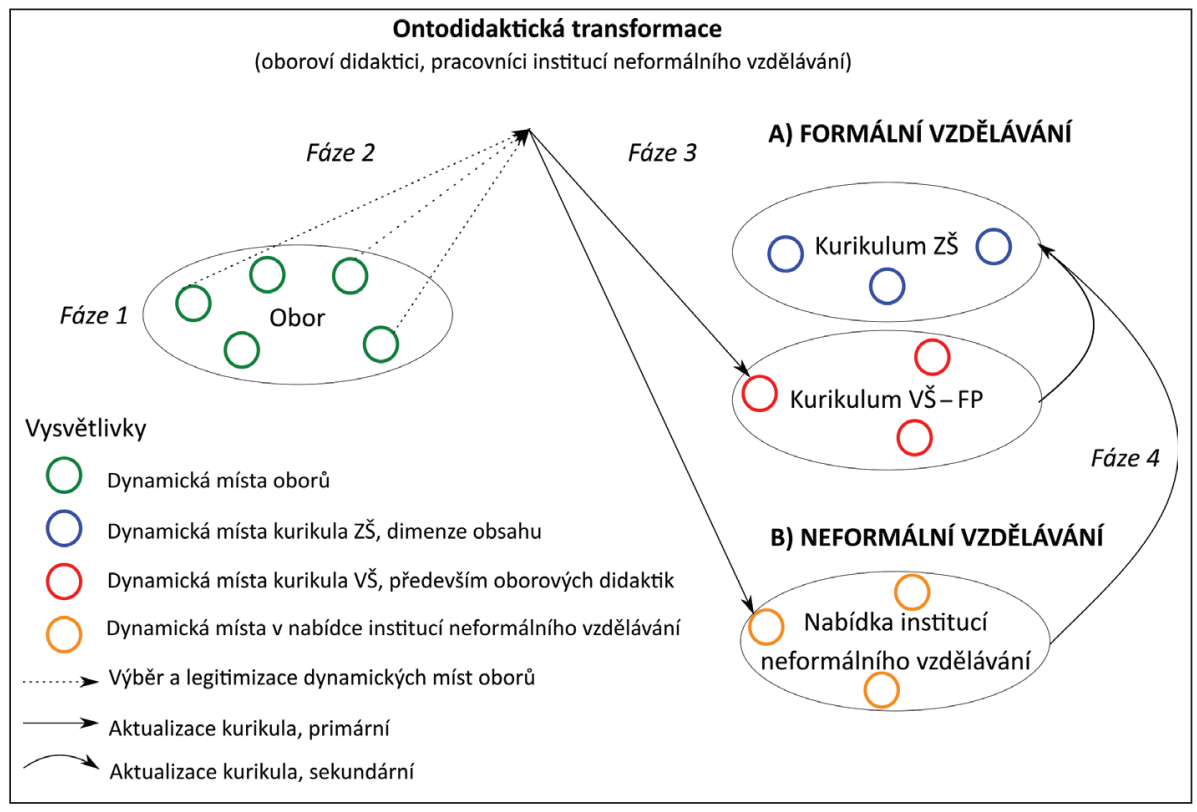

Obr. 1. Dynamická místa oborů a dynamická místa kurikula na různých úrovních zasazená do procesu ontodidaktické transformace podle Janíka et al. (2009)

mít více dílčích příčin, o nichž budeme pojednávat níže. Jejich společným zdrojem je napětí mezi nárokem na noetickou rovnocennost transformovaného obsahu a potřebou jeho didaktické rekonstrukce. Jde o to, že vzdělávací obsah má být z oboru ontodidakticky a psychodidakticky transformován tak, aby zůstával noeticky rovnocenný - izomorfní, tj. aby nedošlo $\mathrm{k}$ jeho nepř́ípustné významové a logické deformaci. Současně však musí být didakticky upraven - rekonstruován, aby se stal pro žáky noeticky př́ístupným (Knecht, 2017, s. 270-272). Didaktická transformace a rekonstrukce jsou tedy dvě strany téže mince, jejichž vztah podmi- ňuje kvalitu učebního prostředí. V modelu didaktické rekonstrukce byly pro jeho zkoumání navrženy tři opěrné body studované ve vzájemných souvislostech (Knecht, 2007, 2017): 1. žák a jeho dosavadní znalosti, představy, myšlenkové procesy apod., 2. vývoj mateřské disciplíny a sledování nových trendů $\mathrm{v}$ rámci mateřských disciplín, 3. výzkum všech elementů učebního prostředí, které mají vliv na žákovu školní úspěšnost (osobnost učitele, vyučovací metody apod.). První složka přitom úzce souvisí s kritickými místy kurikula, protože jejich kritičnost může být mimo jiné způsobená neodhalením nevhodných prekonceptů u žáků 
nebo nesprávnou prací s nimi (Kohout et al., 2019a). Druhá složka je provázána s dynamickými místy kurikula. Propojení kritických a dynamických míst kurikula je tak možné teoreticky uchopit jako „mezihru“ uvedených složek v rámci modelu didaktické rekonstrukce směrem $\mathrm{k}$ didaktickému strukturování učebního prostředí (Kattmann, 2009).

Definování dynamických míst vědních oborů a jejich transformace je $\mathrm{z}$ našeho pohledu důležité především z hlediska aktualizace kurikula (Mentlík et al., 2018; fáze 3 a 4 na obr. 1). Kurikulum chápeme jako obsah vzdělání $v$ návaznosti na vzdělávací cíle ${ }^{2}$ a proces jeho osvojování, tj. jako veškerou zkušenost žáka, kterou získává ve školském prostředí, a činnosti, které jsou spojeny s osvojováním a hodnocením vzdělávacího obsahu (Maňák, Janík \& Švec, 2008).

$\mathrm{V}$ tomto širokém vymezení kurikula je účelné rozlišovat (relativně) statickou či stabilizační stránku - kurikulární dokumenty - a dynamickou stránku - realizaci kurikula během edukace (Hajerová Mủllerová \& Slavík, 2020). Aktualizace kurikula se může urychlit tím, že učitel při realizaci kurikula „obejde“ kurikulární dokumenty, které se nejpomaleji mění, typicky rámcové vzdělávací programy. Tím se však může snížit kvalita ontodidaktické transformace. Proto se aktualizace kurikula musí vyrovnávat $s$ problémem vhodné míry mezi nárokem na aktuálnost a nárokem na promyšlenost a kvalitu didaktické transformace obsahu.
Aktualizace kurikula se potom týká především obsahové dimenze kurikula, tj. obsahu vzdělávání, který má být žákům ve výuce zprostředkován (učivo). Primárně tak jde o aktualizaci nebo zpřesnění stávajícího obsahu kurikula na základě nových vědeckých poznatků. Př́íkladem může být zpřesnění výuky o litosférických deskách a jejich pohybech na základě nových vědeckých poznatků o zemském plášti a jeho vlastnostech při výuce zeměpisu (Hawley \& Lyon, 2017). Tím se aktualizace kurikula z našeho pohledu liší od modernizace kurikula (Maňák et al., 2008), která postihuje především dimenzi ideovou, což je rozměr kurikula zaměřený na cílové hodnoty vzdělávání. Maňák et al. (tamtéž) jako modernizaci označují reakci kurikula na stav společnosti a její potřeby. Např́iklad se tak může jednat o rozšiřování výuky cizích jazyků v souvislosti $s$ rostoucí globalizací, implementaci témat důležitých pro udržitelnost společnosti do výuky (např. environmentální problémy), důraz na celoživotní vzdělávání apod. Za určitých okolností však aktualizace kurikula může podněcovat i nároky na jeho modernizaci, typicky např. v oblasti zavádění informačních technologií do vzdělávání.

$\mathrm{V}$ třetí fázi transformace tedy dochází $\mathrm{k}$ aktualizaci kurikula. Nelze předpokládat, že by aktualizace kurikula základních škol ve většině prŕípadů probíhala přímo, tj. že by učitelé sami prováděli transformaci dynamických míst oborů a implementova-

\footnotetext{
${ }^{2}$ Kurikulum je typické spojením obsahu s cíli. V Rámcovém vzdělávacím programu pro gymnázia (VÚP, 2007) je vzdělávací obsah přímo vymezený jako „propojený celek očekávaných výstupů a učiva“, tj. spojení cílů a vzdělávacího obsahu.
} 
li je do své výuky. Přestože jsme si vědo$\mathrm{mi}$, že řada učitelů zaujatých svým oborem často sleduje novinky v oboru a obohacuje o ně svou výuku, domníváme se, že tuto aktivitu nelze předpokládat u všech učitelů. Kromě toho, jak bylo zmíněno, při těchto jen individuálních iniciativách hrozí větší nebezpečí deformace odborných poznatků. Vzhledem k již tak velkému pracovnímu vytížení učitelů (Kohoutek \& Řehulka, 2011; Krninský, 2012) po nich nelze vyžadovat další systematickou aktivitu týkající se transformace dynamických míst. Dalším důvodem může být problém spojený s reprezentací (uplatnění různých způsobů ztvárnění vzdělávacího obsahu; Janík et al., 2009) dynamických míst. U některých dynamických míst lze předpokládat potřebu využití různých technologií nebo speciálních pomůcek, které pro běžně vybavenou základní školu nemusí být dostupné. $\mathrm{Z}$ těchto důvodů transformaci provádí zejména oboroví didaktici a pracovníci institucí neformálního vzdělávání (typicky science centra) nebo v ideálním př́padě oba aktéŕi ve vzájemné spolupráci. $V$ př́padě oborových didaktiků je žádoucí dynamická místa a návrhy jejich reprezentace zařadit také do výuky oborových didaktik na pedagogických fakultách. Dochází tím k aktualizaci kurikula na úrovni vysokých škol a lze předpokládat, že tato aktualizace bude mít sekundárně vliv na aktualizaci kurikula základních škol, pokud absolventi své zkušenosti ze studia budou aplikovat $\mathrm{v}$ praxi.

Velmi důležitou roli v aktualizaci kurikula základních škol však z našeho pohledu hrají především instituce neformálního vzdělávání, jako jsou science centra, muzea, botanické a zoologické zahrady apod. Jejich expozice, laboratoře a technické vybavení mohou být velmi užitečné př̀i ztvárnění dynamických míst kurikula, což souvisí i s tím, že třeba science centra jsou často přirozeným partnerem pracovišt realizujících oborový výzkum při jeho popularizaci. Aktualizace kurikula základních škol tak může probíhat na základě speciálně připravených programů zacílených právě na výuku dynamických míst pro cílovou skupinu žáků základních škol. $\mathrm{Na}$ procesu transformace se podílí bud' rovnou pracovníci institucí neformálního vzdělávání, nebo dochází ke spolupráci s oborovými didaktiky pedagogických fakult. Konkrétní př́klady řešení dynamických míst $\mathrm{v}$ předmětech fyzika a zeměpis vzniklých ve spolupráci didaktiků $s$ institucemi neformálního vzdělávání a učiteli prezentujeme v kapitole 4.

Dynamická místa kurikula mají velkou perspektivu při práci s talentovanými žáky. Pokud talentovaní žáci či studenti bez problému zvládnou běžné učivo, právě atraktivní novinky z oborů, často založené na pochopení komplikovaného multidisciplinárního odborného základu, mohou přispět $\mathrm{k}$ jejich dalšímu rozvoji.

\section{Metody ZJIŠŤováNí DYNAMICKÝCH MÍST}

\subsection{Metoda analýzy počtu vědeckých článků}

Metoda se zaměřuje na vymezení dynamických míst oboru (viz fáze 1 na obr. 1) a vychází z předpokladu, že 
v rámci dynamicky se rozvíjejících oblastí oboru dochází ke generování nových poznatků, které jsou publikovány ve vědeckých časopisech (Mentlík, 2016; Mentlík et al., 2018). Dynamická místa oboru tak lze vymezit na základě analýzy počtu originálních publikací $\mathrm{v}$ prestižních vědeckých časopisech za jednotlivé oblasti oboru. Čím více publikací daná oblast vykazuje, tím dynamičtější rozvoj lze u ní předpokládat. Navržená metoda vychází ze základní bibliometrické analýzy, kterou lze standardně využívat pro měření vědeckého výkonu $\mathrm{v}$ mezinárodním kontextu nebo k popsání vývoje vědeckého oboru či disciplíny (Glänzel, 2003). V rámci výše popsaného procesu transformace dynamických míst lze tuto metodu využít pouze pro prvotní vymezení dynamických míst oborů, po kterém musí následovat proces výběru a legitimizace. Analýzu lze provést na národní i mezinárodní úrovni. Následující odstavce uvádějí př́klady dříve využitých metodických postupů.

$\mathrm{Na}$ národní úrovni zpracoval analýzu vědeckých článků zaměřených na geografii Mentlík (2016). Ve studii byl proveden rozbor článků českých autorů publikovaných ve významných zahraničních časopisech během trríletého období. Výstupy byly podle obsahu (zjištěno na základě názvu článku nebo rozboru abstraktu) dále rozděleny do skupin odpovídajících systému členění geografických disciplín. Pro každou skupinu byly následně sečteny počty publikací a tím bylo zjištěno, které disciplíny se rozvíjejí nejdynamičtěji. V každé skupině byla sledována i dílčí témata, která v rámci disciplíny dominovala.
S cílem určit aktuální dynamická místa fyzické geografie na mezinárodní úrovni byla poté provedena analýza vědeckých výstupů v prestižních časopisech Nature Geoscience a Progress in Physical Geography (Pluháčková, 2018). Během tř́letého období byly publikované výstupy $\mathrm{v}$ těchto časopisech tříděny do kategorií (např. klimatologie a vědy o atmosfére) a podkategorií (např. klimatologie - predikce do budoucna), které využívá časopis $\mathrm{Na}$ ture Geoscience. Každý publikovaný článek byl na základě názvu nebo abstraktu zařazen do př́íslušné kategorie a podkategorie. V závěru bylo vyhodnoceno, která kategorie a podkategorie zaznamenala nejvíce bodů. Tyto kategorie lze vnímat jako nejdynamičtěji se rozvíjející místa fyzické geografie.

Studie na mezinárodní úrovni využívající analýzu počtu publikací provedla také Gurnellová (2018). Ta prezentuje analýzu vývoje počtu publikací v časopise Progress in Physical Geography za jednotlivé disciplíny fyzické geografie $\mathrm{v}$ rámci časového úseku 25 let. Cílem této studie není vymezení současných dynamických míst fyzické geografie, ale spíše sledování vývoje jednotlivých disciplín a trendů $\mathrm{v}$ různých časových obdobích.

\subsection{Metoda dotazování učitelů}

Metoda dotazování učitelů může být využita jako doplňková metoda ke zjištění dynamických míst oboru (fáze 1, obr. 1) a zároveň pro jejich výběr a legitimizaci (fáze 2, obr. 1). Nelze předpokládat, že učitelé systematicky a podrobně sledují 
rozvoj vědních disciplín, z nichž vycházejí předměty, které vyučují, a byli by tak schopni objektivně vymezit dynamická místa oborů. Mohou ale na základě svého subjektivního vnímání pomoci doplnit výzkum primárně řešený metodou analýzy počtu článků popsaný výše nebo metodou expertního posouzení (viz kap. 3.3). Obzvlášt témata nebo oblasti oborů, u kterých dojde ke shodě mezi výzkumníky a učiteli, mohou být vhodná pro výběr dynamických míst $\mathrm{k}$ procesu transformace. Fakt, že témata definuje učitel z praxe, zároveň zajištuje, že vybraná místa budou pravděpodobně provázaná $s$ kurikulem, což je jednou z navržených podmínek legitimizace. Dále lze předpokládat, že u témat vybraných učiteli bude z jejich strany zájem o př́padné ztvárnění institucemi neformálního vzdělávání nebo oborovými didaktiky.

Metoda dotazování byla využita pro zjištění dynamických míst $\mathrm{v}$ rámci řešení projektu Didaktika - Člověk a př́roda A za obor Geografie (Pluháčková et al., 2019). Učitelé odpovídali v dotazníku na šest otázek, přičemž stěžejní byla otázka zaměřená na zjištění dynamicky se rozvíjejících oblastí v geografii z jejich pohledu. Kromě toho dotazník obsahoval také otázku na učivo, které podle učitelů rychle zastarává. Cílem zařazení této otázky bylo odlišit od sebe dynamicky se rozvíjející oblasti od těch, které rychle ztrácejí svou aktuálnost (např. různé statistické údaje o státech a regionech, které bývají součástí výuky zeměpisu). Výsledky dotazníku byly zohledněny při sestavování vzdělávacích programů zaměřených na řešení dy- namických míst pro základní školy, které vznikly v rámci projektu. Ukázka jednoho $\mathrm{z}$ nich je prezentovaná v kapitole 4.2.

\subsection{Metoda expertního posouzení}

Stanovení dynamických míst oborů na základě analýzy počtu vědeckých publikací popisované v kapitole 3.1 či např́íklad zjištování míry citovanosti může být přinejmenším $\mathrm{v}$ některých oborech problematické. Jako ilustraci uved'me poznatky ze studie publikované v časopise Nature (van Noorden, Maren \& Nuzzo, 2014), jež byla zaměrena na určení nejcitovanějších článků podle jednotlivých oborů $\mathrm{v}$ rámci databáze Web of Science. Bylo zjišstěno, že např́íklad ve fyzice nemají největší počty citací práce týkající se převratných objevů, ale spíše metodické studie týkající se výpočtových postupů v oblasti kvantové fyziky, o jejichž existenci nemají laici a pravděpodobně ani odborníci mimo tuto oblast fyziky ani zdání. Hojně citovány jsou rovněž studie pocházející z oblastí, kde rozhodně nepanuje vědecký konsenzus ohledně př́nosu prŕslušných teorií (např. teorie strun). Vedle počtu vědeckých publikací či určení míry citovanosti je možné se oprít o řadu dalších metrik (Nobelovy ceny, počty konferencí, objem prostředků alokovaných na výzkum apod.), každá $\mathrm{z}$ těchto metod však $\mathrm{v}$ sobě skrývá určitá rizika (např. u Nobelových cen je běžné, že jsou udělovány za objevy staré i několik desítek let, není tak nijak zaručeno, že vystihují skutečně aktuální dynamická místa oborů). 
Uvedené př́klady demonstrují skutečnost, že ani stanovení dynamických míst oborů, ani jejich následná legitimizace se nejspíše neobejdou bez expertního posouzení, které bude do jisté míry vycházet $\mathrm{z}$ analýzy trendů $\mathrm{v}$ oboru (viz kap. 3.1), resp. z poznatků získaných od učitelů (viz kap. 3.2). Fundamentální otázkou zde je, kdo by měli být experti posuzující uvedené body a jakým způsobem by toto posouzení mělo proběhnout.

Z hlediska samotného stanovení dynamických míst oborů je $\mathrm{v}$ historii možné najít pokusy o expertní definování současných trendů různých vědeckých disciplín. Asi nejvýznamnějším počinem v této oblasti byla studie Organizace spojených národů, kterou zpracoval na přelomu padesátých a šedesátých let 20 . století tým pod vedením francouzského fyzika Pierra Augera (Auger, 1961). V jejím rámci byly na základě konzultací $s$ experty ${ }^{3}$ definovány významné trendy $\mathrm{v}$ mnoha vědních oblastech, matematikou počínaje a zemědělskými vědami konče. ${ }^{4}$ Navzdory značnému rozsahu studie v ní však nikde není popsána metodika užitá pro výběr těchto trendů a nejsou zahrnuty žádné datové analýzy. Ačkoli OSN (přesněji UNESCO jako její součást) od té doby pravidelně zpracovává velmi obsáhlé reporty týkající se stavu vědeckého výzkumu ve svě- tě, pokus o ucelené globální definování klíčových výzkumných trendů již nebyl opakován ${ }^{5}$ a uvedené studie jsou spíše zaměřeny na organizační aspekty výzkumu jako celku, jeho financování, genderové a sociální otázky apod. Na bázi jednotlivých oborů lze občas vysledovat pokusy o podchycení aktuálních klíčových trendů a souvisejících významných objevů. $\mathrm{V}$ prŕpadě fyziky je v tomto směru aktivní např́iklad časopis Physics World, který opakovaně realizoval ankety mezi fyziky týkající se nejvýznamnějších aktuálních objevů, ale třeba i nejdůležitějších fyziků či fyzikálních experimentů v historii. Z hlediska zařazení do ankety přitom autoři uvedli, že se zaměřili na významné fyziky, kteří však zároveň „přemýšlejí do hloubky o fyzice jako vědě a dokáží pohlédnout i za svůj vlastní výzkum“. Dále byl kladen důraz na zastoupení různých věkových skupin, genderovou vyváženost a také rovnoměrné zastoupení teoretiků a experimentálních fyziků (Durrani \& Rogers, 1999). Ačkoli výběr byl popsán bez bližších detailů, je zde nastíněna velice důležitá otázka, a to jakým způsobem vybírat dynamická místa definovaná odborníky tak, aby bylo možné získat relevantní údaje. $S$ uvedenými rámcovými kritérii přitom lze souhlasit. Jako doplňující kritérium by s ohledem na následnou

\footnotetext{
${ }^{3} \mathrm{~V}$ př́loze ke studii jsou uvedeny seznamy několika set aktivních vědců zapojených do př́pravy reportu. Konzultace byly realizovány rovněž s představiteli mnoha desítek mezinárodních i národních výzkumných institucí a profesních organizací.

${ }^{4}$ Vủbec nebyly zahrnuty humanitní ani společenskovědní obory, pokrytí u prírodovědných, technických či lékařských oborů však bylo důkladné.

${ }^{5}$ To možná souvisí se stále prudším rozvojem počtu vědeckých disciplín a zároveň užší specializací vědců, což by velmi silně komplikovalo zpracování skutečně vypovídajícího reportu v uceleném počtu lidí.
} 
vazbu $\mathrm{k}$ dynamickým místům kurikula bylo vhodné zaměřit se na odborníky, kteří mají vztah $\mathrm{k}$ výuce daných oborů na nižších stupních škol (např. tím, že se účastní i didaktických konferencí, pravidelně realizují přednášky pro žáky ZŠ či $S S \check{S}$ ). Celkově se však kloníme k názoru, že samotný výběr dynamických míst oborů by měl být primárně $\mathrm{v}$ režii odborníků realizujících $\mathrm{v}$ dané oblasti $\mathrm{v}$ současnosti aktivní výzkum.

$\mathrm{Z}$ hlediska legitimizace dynamických míst oborů směrem k dynamickým místům kurikula se domníváme, že by mělo expertní posouzení probíhat v panelu, který by zahrnoval nejen vědce, ale i další odborníky z oblasti formálního i neformálního vzdělávání. ${ }^{6}$ Pokládáme přitom pro účely expertního posouzení daných dynamických míst za potřebné definovat jednoznačná a oborově specifická kritéria, která by měla být $\mathrm{v}$ rámci legitimizace splněna. Pro př́pad fyziky jsme přitom navrhli kritéria uvedená v kapitole 2 tohoto textu a detailně v monografii Kohouta et al. (2019a, s. 9-10). Z hlediska složení expertního panelu přitom pokládáme za vhodné vyjít z toho, které skupiny zahrnuli do expertního zjištování současných trendů $\mathrm{v}$ chemickém vzdělávání autoři Vamvakeros, Pavlatou \& Spyrellis (2010). Ti oslovili následujících šest skupin, jejichž pohledy následně komparovali:

- akademici realizující výzkum v samotné chemii, avšak $s$ přesahem do oblasti vzdělávání;
- akademici působící v oblasti didaktiky chemie či historie a filozofie vědy;

- odborníci na chemii na nižších stupních vzdělávání působící např. ve státních pedagogických institutech či centrech pro pedagogický výzkum;

- učitelé chemie na nižších stupních škol, kteří se významněji zapojují do komunity a mají zkušenosti s tvorbou či oponováním učebnic, metodických materiálů apod.;

- mladí výzkumníci (Ph.D. studenti) z oblasti odborné chemie či didaktiky chemie;

- odborníci z oblasti průmyslu majícího relevanci k chemii.

$\mathrm{V}$ našem př́padě nepokládáme za nutné zapojení páté skupiny (Ph.D. studenti). Především v oblasti oborové didaktiky však tito studenti obvykle spadají v českých poměrech zároveň do některé $\mathrm{z}$ dalších skupin (učitelé na nižších stupních škol, akademičtí pracovníci), $\mathrm{v}$ jejichž rámci zapojeni být mohou. Naopak se domníváme, že by v panelu expertů měli být rozhodně zastoupeni pracovníci science center zaměření na daný obor tak, aby do výběru vnesli i pohled neformálního vzdělávání. Rozhodně pokládáme $\mathrm{v}$ souladu s Benczem a Hodsonem (1999) za nutné zapojení učitelů z praxe i aktivních vědců $\mathrm{v}$ daném oboru do tohoto procesu majícího relevanci směrem $\mathrm{k}$ tvorbě kurikula. Jako potenciálně př́nosné vnímáme i zapojení odborníků z průmyslu, kteří by však měli mít hlubší vztah $\mathrm{k}$ problematice

\footnotetext{
${ }^{6}$ Zapojení zástupců neformálního vzdělávání pokládáme přitom za velice důležité i s ohledem na to, že dynamická místa kurikula jsou námi chápána právě jako most mezi formálním a neformálním vzděláváním.

${ }^{7}$ Převedeno na české poměry by se jednalo například o odborné pracovníky Národního pedagogického institutu ČR.
} 
vzdělávání. $V$ rámci prvotního předběžného výběru dynamických míst fyzikálního kurikula (viz část 4.2) byli v panelu pracujícím podle výše uvedených kritérií zastoupeni odborníci pracující v oblasti fyziky i didaktiky fyziky, učitelé z praxe a rovněž pracovníci science center.

\section{4. ŘEŠENÍ DYNAMICKÝCH}

\section{MÍST - PŘÍKLADY DOBRÉ PRAXE}

\subsection{Příklad řešení dynamického místa z kurikula fyziky}

Dynamická místa kurikula v oblasti fyziky byla $\mathrm{v}$ rámci projektu Didaktika A - Člověk a prríroda, v němž participovali pracovníci čtyř univerzit, dvou science center a učitelé $Z \breve{S}$, stanovena na základě expertního posouzení panelem pracujícím podle zásad uvedených v části 3.3 tohoto článku. Výběr poté probíhal na základě jasných kritérií stanovených panelem a uvedených v části 2 a detailně v knize Kohouta et al. (2019a, s. 9-10). V panelu působilo celkem šest členů, přičemž část $\mathrm{z}$ nich spadala do více než jedné $\mathrm{z}$ uvedených kategorií (jednalo se např. o jedince pracujícího ještě v nedávné minulosti v oblasti inženýrské fyziky, který se v současné době věnuje didaktice fyziky a zároveň působí na částečný úvazek jako učitel v regionálním školství). Bylo projednáno celkem sedm návrhů na dynamická místa, z nichž čtyři byly akceptovány. Pro základní školy tak byla stanovena dynamická místa Magnetická kapalina, Termografie, Levitace vysokoteplotního supravodiče a Materiály s tvarovou pamě- tí. Zde uvedeme jako konkrétní př́klad řešení dynamického místa Magnetické kapaliny, jež je součástí komplexnějšího výukového programu zaměřeného na problematiku nanotechnologií. Zdůrazníme přitom souvislost tohoto dynamického místa kurikula s kritickým místem Magnetické indukční čáry, které bylo stanoveno $\mathrm{v}$ předchozím výzkumu na základě rozhovorů $s$ učiteli, analýzy kurikulárních dokumentů a rozboru úspěšnosti českých žáků v úlohách mezinárodního srovnávacího šetření TIMSS (Kohout et al., 2019b). Prezentovaný př́íklad vychází $\mathrm{z}$ programu realizovaného $\mathrm{v}$ interaktivním muzeu vědy Pevnost poznání v Olomouci, podobným způsobem je však tato problematika řešena i $v$ dalších science centrech (např. v liberecké iQLANDII či ostravském Velkém světě techniky).

Nanotechnologie patří mezi rychle se rozvíjející vědecké obory 21 . století. Zahrnují zkoumání, vytváření a využívání materiálů a zařízení v nanoměŕítku. Již dnes se můžeme setkat $s$ řadou spotřebitelských výrobků, které obsahují nanomateriály nebo byly vyrobeny díky nanotechnologiím. Jde tedy o oblast poznatků, které splňují první fázi procesu transformace dynamických míst. Pokud se zaměríme i na další kritéria kladená na dynamická místa, tak i ta řada poznatků z nanotechnologií splňuje a je možné je zařadit do fyzikálního kurikula na základních i středních školách.

Ve spolupráci didaktiků fyziky a odborníků na nanotechnologie $\mathrm{z}$ Př́rodovědecké fakulty Univerzity Palackého vznikl výukový program zaměřený 
na tuto problematiku. Tento program slouží k přiblížení základních konceptů nanotechnologií a jejich využití v běžném životě pro žáky základních a středních škol. Ačkoli je nanosvět pouhým okem neviditelný, lze ho žákům demonstrovat pomocí názorných pomůcek a modelů. Je tedy splněno i další kritérium výběru a legitimizace dynamických míst.

Jedna z částí programu je věnována nanočásticím na bázi železa a jejich využití při čištění kontaminovaných vod. Tyto nanočástice jsou obsaženy v magnetické kapalině, jejíž vlastnosti jsou magnetickým polem ovlivňovány. V programu si žáci vyzkoušejí, jak magnet působí na magnetickou kapalinu, a porovnají chování této kapaliny $s$ železnými pilinami. Kapalina i piliny jsou vyrobeny ze stejného materiálu, ale chovají se odlišně. Rozdíl je ve velikosti částic, která ovlivňuje, jak bude kapali- na na magnetické pole reagovat. Co však žáky zaujme nejvíce je, že se po přiložení magnetu $\mathrm{k}$ nádobě $\mathrm{s}$ magnetickou kapalinou vytvoří ,ježek“, jehož bodliny ukazují směr magnetických indukčních čar použitého magnetu. Díky tomu dochází k propojení dynamických a kritických míst kurikula fyziky.

$S$ magnetickými indukčními čarami se žáci setkají již v 6. ročníku na základní škole, kde pomocí řetězců pilin zobrazují magnetické pole na podložce položené na magnetu. Problém je v tom, že piliny nám umožňují zobrazit jen ty čáry, které leží v rovině podložky. Jelikož indukční čáry můžeme určovat $\mathrm{v}$ celém prostoru magnetického pole, je potřeba i prostorové zobrazení. To mohou učiteli poskytnout i magnetické kapaliny obsahující nanočástice na bázi železa. Toto dynamické místo kurikula je provázáno se stávajícím fyzikálním kurikulem

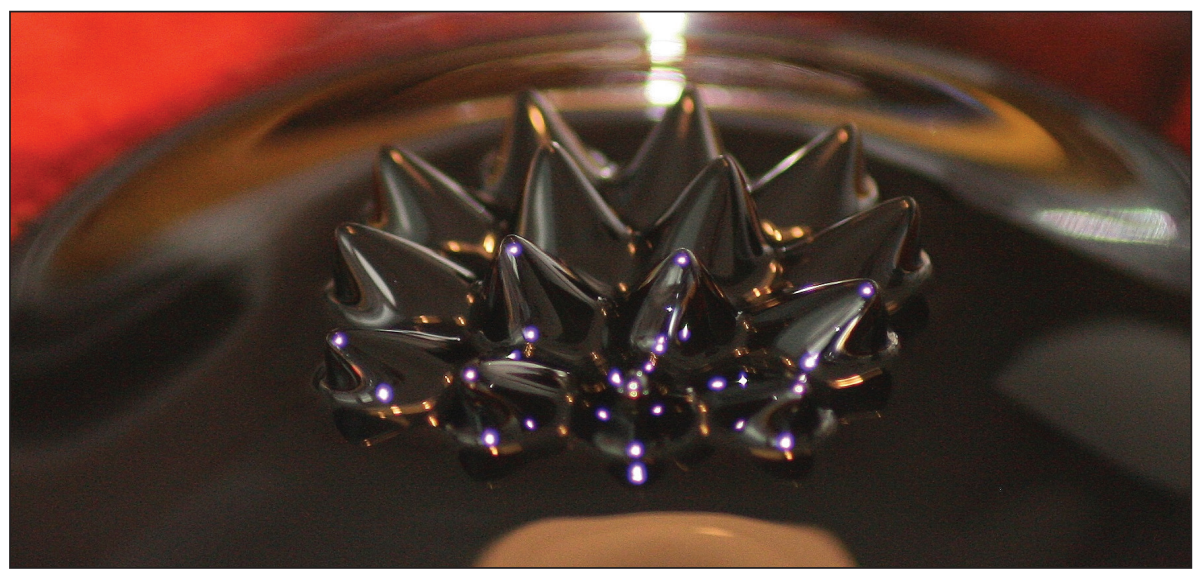

Obr. 2. „Ježek“, kterého vytvoří magnetická kapalina po přiložení magnetu 
na základní škole a lze jej demonstrovat i v prostředí běžné třídy (ačkoli pravděpodobně ne $\mathrm{v}$ takové kvalitě a rozsahu jako v science centrech). Magnetickou kapalinu lze zakoupit v obchodech, které prodávají magnety.

Uvedený vzdělávací program je v nabídce Pevnosti poznání od školního roku 2015/2016, kdy byl proveden i rámcový výzkum jeho efektivity a vnímání žáky (Kolářová \& Rálišová, 2017). Výhodou neformálního vzdělávání je, že mohl vzniknout ucelený výukový program věnovaný pouze nanomateriálům, a žákům tak mohou být představeny postupně základní koncepty, které jsou důležité pro pochopení dalších poznatků a aplikací nanotechnologií. To bohužel není možné vytvořit $\mathrm{v}$ rámci stávajícího kurikula fyziky z různých důvodů, např́klad kvůli časové dotaci předmětu fyzika na základních školách. Jednou z možností je integrovat tuto problematiku do již existujících školních vzdělávacích programů tak, aby byly provázány se stávajícím obsahem kurikula, jak bylo ukázáno na př́íkladu magnetické kapaliny. To by nicméně vyžadovalo další př́ípravu a vytížení učitele, který se při výuce podobných témat nemusí cítit komfortně, pokud danou problematikou neprošel při svém studiu na vysoké škole. Zde se tedy ukazuje další výhoda institucí neformálního vzdělávání, ve kterých na vzniku výukového programu mohou spolupracovat pracovníci institucí s oborovými didaktiky a odborníky v daném oboru a získat tak potřebné znalosti pro realizaci výukového programu.

\subsection{Příklad řešení dynamického místa z kurikula zeměpisu}

$\mathrm{V}$ rámci projektu Didaktika - Člověk a príroda A byly za obor geografie vytvořeny dva výukové programy, které vznikly ve spolupráci oborových didaktiků a pracovníků science center s cílem pomoci učitelům zeměpisu a jejich žákům na 2 . stupni základních škol se ztvárněním vybraných dynamických míst. $\mathrm{V}$ této kapitole bude podrobněji představen jeden návrh výukového programu, který se věnuje moderním technologiím využitým v kartografii. Jedná se o modelový př́klad transformace dynamického místa oboru s cílem aktualizace kurikula základní školy.

Téma vzdělávacího programu bylo vybráno (fáze 1) na základě výsledků dotazníků s učiteli (popis metody viz kap. 3.2). Tematický celek Mapy je podle učitelů po tematickém celku Socioekonomická sféra Země druhým nejdynamičtěji se rozvíjejícím v rámci oboru geografie. Pro návrh vzdělávacího programu byl tematický celek Mapy vybrán proto, že lépe splňoval kritéria výběru a legitimizace (fáze 2) - především kritérium názorné a atraktivní demonstrace. Do projektu zapojená science centra (Svět techniky Ostrava a iQLANDIA v Liberci), která ztvárnila zjištěná dynamická místa, své expozice obecně zaměřují především na prrírodovědné a technické obory a mají tak lepší možnosti pro demonstraci právě těchto oborů. V science centru iQLANDIA navíc již byly $\mathrm{k}$ dispozici exponáty, které se daly vhodně využít pro návrh vzdělávacího programu zaměřeného na využití 
technologií v moderní kartografii. Toto zaměření vyplynulo $\mathrm{z}$ analýzy témat, která učitelé v dotazníku v rámci tematického celku Mapy uváděli jako nejdynamičtější: Moderní technologie v kartografii; Moderní kartografie a GPS systémy; Dálkový průzkum Země; GPS; Mapování a geoinformatika; Nové technologie v kartografii. Fakt, že se jedná o dynamicky se rozvíjející oblast, potvrzuje i metoda analýzy počtu publikací provedená na národní úrovni, ze které jako dynamická vyšla oblast zabývající se dalším rozvojem geografických informačních systémů (dále jen GIS; Mentlík, 2016).
Při procesu výběru a legitimizace (fáze 2) byla dodržena kritéria vymezená $\mathrm{v}$ kapitole 2. Téma je provázané se stávajícím kurikulem základní školy a tematicky spadá zejména do vzdělávacího obsahu Geografické informace, zdroje dat, kartografie a topografie, vymezeného v Rámcovém vzdělávacím programu pro základní vzdělávání (MŠMT, 2017). Téma má jednoznačné a pro žáky představitelné dopady do běžného života (využívání navigace, aplikace GIS v rámci integrovaného záchranného systému, využívání satelitních snímků pro předpověd' počasí apod.). $\mathrm{V}$ neposlední řadě bylo vyhodnoceno, že

Tab. 1. Popis aktivit a exponátů zařazených do vzdělávacího programu Moderní kartografie a GPS ve science centru iQLANDIA

\begin{tabular}{|c|c|c|}
\hline Aktivita & Stručný popis & Využitý exponát \\
\hline 1 & $\begin{array}{l}\text { Demonstrace oběžných drah satelitů a princip } \\
\text { fungování GPS, detailní prohlídka jednoho ze } \\
\text { satelitů, výklad s diskusí }\end{array}$ & $\begin{array}{l}\text { Projekce promítaná na kulovou } \\
\text { plochu planetária }\end{array}$ \\
\hline 2 & $\begin{array}{c}\text { Princip vzniku družicových snímků a příklady } \\
\text { jejich využití, problematika vlnové délky a barev- } \\
\text { ného spektra, výklad s diskusí a samostatná práce } \\
\text { žáků s pracovním listem }\end{array}$ & $\begin{array}{l}\text { „Podlahová mapa“- satelitní } \\
\text { snímek družice LANDSAT } \\
\text { promítaný na podlahu místnosti } \\
\text { (obr. 3A) }\end{array}$ \\
\hline 3 & $\begin{array}{l}\text { Princip vzniku leteckých snímků a prýklady } \\
\text { jejich využití, analýza změn na historickém } \\
\text { a moderním leteckém snímku města, diskuse }\end{array}$ & $\begin{array}{c}\text { Letecké snímky města Liberec } \\
\text { promítané na plátno s možností } \\
\text { přepínání pomocí zařízení Kinect } \\
\text { (obr. 3B) }\end{array}$ \\
\hline 4 & $\begin{array}{l}\text { Princip GIS a příklady využití v běžném životě, } \\
\text { samostatná práce a diskuse }\end{array}$ & $\begin{array}{l}\text { Dotykové panely s ukázkami GIS } \\
\text { na různá témata (obr. 3D a 3E) }\end{array}$ \\
\hline 5 & $\begin{array}{l}\text { Tvorba vlastních „map“ pomocí modelů z písku } \\
\text { - projektor na písek podle reliéfu modelu vykres- } \\
\text { lí jednu z pěti vrstev (např. vrstevnice), s každou } \\
\text { změnou modelu se mění i promítaný obraz, } \\
\text { princip využívání vrstev podobně jako v GIS, } \\
\text { samostatná práce a diskuse }\end{array}$ & $\begin{array}{l}\text { Interaktivní pískoviště - box } \\
\text { s jemným pískem a projektorem } \\
\text { umístěným nad ním (obr. 3C) }\end{array}$ \\
\hline
\end{tabular}


téma lze vhodně demonstrovat pomocí názorných a pro žáky atraktivních pomůcek, které již jsou $\mathrm{k}$ dispozici $\mathrm{v}$ rámci expozic science centra iQLANDIA v Liberci.
V rámci fáze 3 vznikl vzdělávací program s názvem Moderní kartografie a GPS, který byl vytvořen pracovníky science centra iQLANDIA. Z již existujících
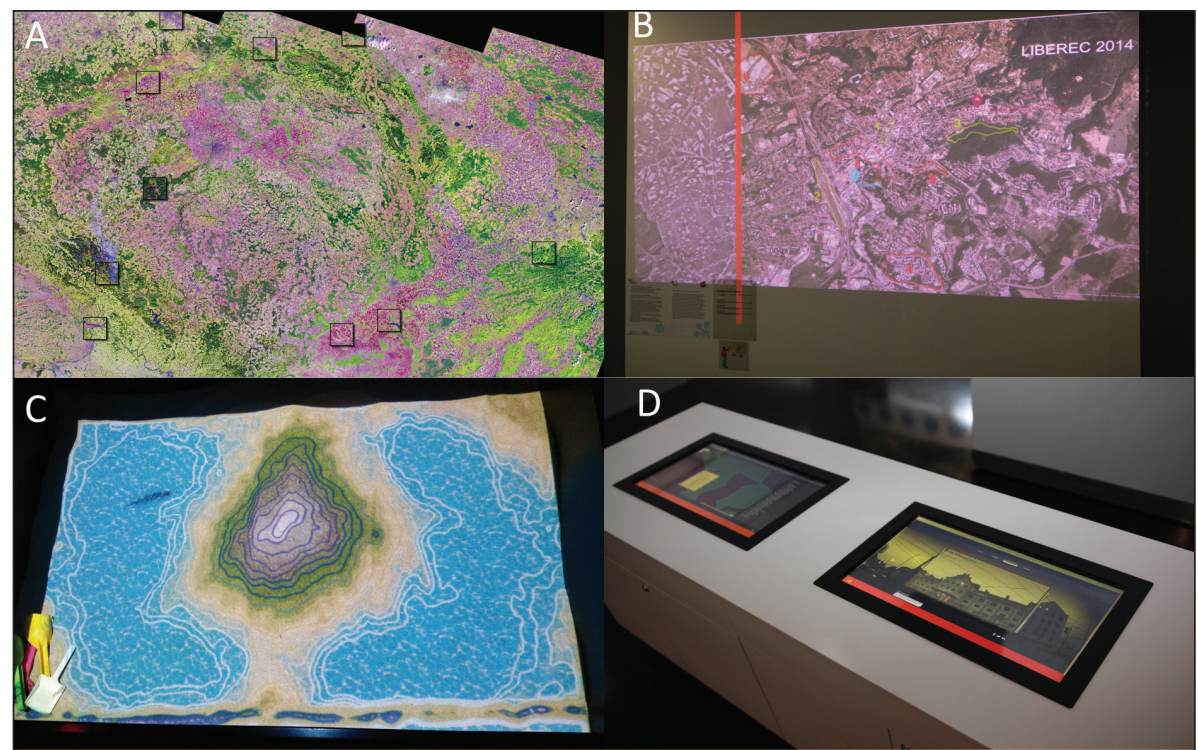

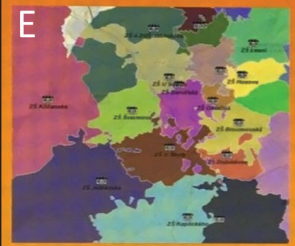

Školské obvody v Liberci

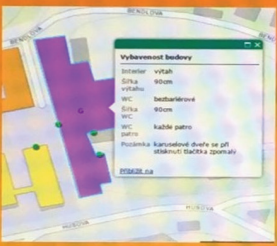

Bezbariérová dostupnost TUL
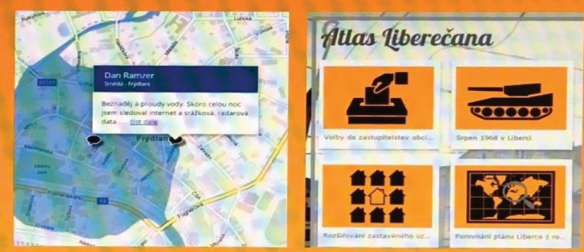

Voda blízko nás

Atlas Liberečana

Obr. 3. Ukázky exponátů zařazených do vzdělávacího programu Moderní kartografie a GPS v science centru iQLANDIA v Liberci: A - „Podlahová mapa“ - satelitní snímek družice LANDSAT promítaný na podlahu místnosti s vyznačenými lokalitami z pracovního listu pro žáky; B - projekce historického a moderního leteckého snímku města Liberec, na kterém žáci hledají změny a příčiny těchto změn - přepínání snímků pomocí zařízení Kinect; $\mathbf{C}$ - exponát Interaktivní pískoviště s př́kladem modelu krajiny a s vykreslením vrstev vodních ploch a vrstevnic; D - panely s dotykovými obrazovkami, na kterých si žáci mohou prohlížet př́klady využití GIS; E - úvodní obrazovka panelu s tématy zpracovanými v GIS 
exponátů byly vybrány ty, které se nejvíce hodily do navrhovaného programu a následně byly doplněny o pracovní listy pro žáky a o metodické listy pro pracovníky science centra. Navržený program se skládá z pěti aktivit s exponáty (jejich stručný popis viz tab. 1), přičemž školy budou moci využít nabízený výukový program jako celek nebo si vybrat jen dílčí aktivity, které odpovídají jejich požadavkům.

Navržený výukový program prozatím nebyl $\mathrm{v}$ uvedené podobě zařazen do nabídky výukových programů science centra iQLANDIA, nabízen by měl být pro školní rok 2020/2021. V tuto chvíli tak nejsou $\mathrm{k}$ dispozici žákovské ani učitelské zpětné vazby. Je tedy nutné podotknout, že $\mathrm{v}$ tomto prípadě se zatím jedná o „potenciální př́klad dobré praxe“. Po uvedení programu do nabídky science centra bude moci docházet $\mathrm{k}$ aktualizaci kurikula základních škol, tedy $\mathrm{k}$ naplnění fáze 4 .

Kromě ztvárnění dynamického místa by měl navržený vzdělávací program díky využití aktivizujících a názorně demonstračních úloh s exponáty pomoci učitelům i s řešením míst kritických. Mezi zjištěná kritická místa patří témata Orientace na mapě a Práce $s$ mapou (Pluháčková et al., 2019). Díky exponátu Interaktivní pískoviště lze žákům názorně demonstrovat téma vrstevnic (kritické místo zjištěné na nižší hierarchické úrovni). Dovednost orientace na mapě si žáci procvičují díky exponátům zaměřeným na satelitní a letecké snímky, u kterých mají za úkol orientovat se $\mathrm{v}$ mapách různých měřítek.

\section{ZÁVĚRY}

V rámci studie jsme definovali pojem dynamická mista oborů, který jsme zasadili do procesu obsahové transformace, jejímž cílem je aktualizace kurikula na různých úrovních. Dále jsme navrhli a popsali komplexní postup, jak lze $\mathrm{k}$ aktualizaci kurikula přistupovat $s$ tím, že rozlišujeme aktualizaci primární (aktualizace studijních programů na úrovni vysokých škol a zejména pedagogických fakult a aktualizace nabídky institucí neformálního vzdělávání) a sekundární (aktualizace kurikula základních a prípadně i středních škol na základě působení absolventů pedagogických fakult a na základě působení institucí neformálního vzdělávání). Součástí postupu jsou návrhy metod sloužících k vymezení dynamických míst, které byly ověřeny. $\mathrm{Na}$ ně navazuje návrh souboru kritérií vhodných pro výběr a legitimizaci dynamických míst v oboru fyziky. Aplikaci těchto kritérií doporučujeme $\mathrm{v}$ rámci procesu výběru a legitimizace dynamických míst pro jejich transformaci do kurikulárního obsahu obecně.

Konstrukt dynamických míst významně propojuje formální a neformální vzdělávání. Ukázalo se, že při vymezování, výběru a legitimizaci i samotném ztvárnění dynamických míst je žádoucí vzájemná spolupráce zástupců formálního (oboroví didaktici, učitelé z praxe) a neformálního vzdělávání (pracovníci science center a dalších institucí neformálního vzdělávání), kdy oba aktéři přinášejí svůj pohled na danou problematiku. Kromě výše uvedených aktérů se do řešení 
problematiky dynamických míst ukazuje jako vhodné zahrnout také samotné výzkumníky z oboru, kteří tvoří čtvrtý vrchol pomyslného čtyřúhelníku zapojených aktérů (oboroví didaktici, pracovníci institucí neformálního vzdělávání, učitelé a výzkumníci). $Z$ našeho pohledu by spolupráce všech těchto stran měla zamezit výskytu negativních aspektů, které by se při řešení dynamických míst mohly vyskytnout. Jedná se zejména o didaktické formalismy (Janík et al., 2013; Slavík et al., 2017), mezi které patří utajené a odcizené poznávání. Utajené poznávání znamená, že vyučovací a učební aktivity žákům skrývají souvislost $s$ instrumentální praxí oboru, tj. s odborným oborovým jednáním, jazykem nebo myšlením. K utajenému poznávání by mohlo docházet $\mathrm{v}$ př́padě přecenění atraktivity ztvárnění oborových obsahů, která může vést $\mathrm{k}$ absenci potřeby obsahům porozumět. Typicky se může jednat o tzv. hands-on aktivity, které se často vyskytují v prŕípadě neformálního vzdělávání (Cloutier, Dwyer \& Sherrod, 2016). Jejich účelem je pomocí manipulace $s$ exponáty, skrze hry nebo efektní pokusy zvýšit nadšení z objevování nových poznatků, přičemž však tyto aktivity nemusí dostatečně podporovat hlubší porozumění a promýšlení obsahů. Chybí tak potřebná vyváženost $s$ tzv. minds-on aktivitami, které naopak hlubší porozumění problematice vyžadují, často však postrádají atraktivitu. Právě přítomnost výzkumníků a oborových didaktiků v projektech řešících dynamická místa by měla zamezit př́padům, ve kterých by docházelo $\mathrm{k}$ utajenému poznávání. Př́i- tomnost zástupců institucí neformálního vzdělávání a učitelů z praxe by naopak měla předcházet situacím, ve kterých by docházelo $\mathrm{k}$ odcizenému poznávání. To se projevuje odtržením obsahu od žákovských činností a zkušeností a následnou ztrátou motivace žáků $\mathrm{k}$ porozumění. Kromě toho mají instituce neformálního vzdělávání díky dobře vybaveným expozicím, laboratořím a dostupnosti moderních technologií a speciálních pomůcek velký potenciál pro reprezentaci vybraných a legitimizovaných dynamických míst oborů. $\mathrm{V}$ prrípadě jejich ztvárnění a nabídnutí ve formě vzdělávacích programů školám tak dochází $\mathrm{k}$ aktualizaci kurikula formálního vzdělávání, přičemž spolupráce všech výše uvedených aktérů by měla garantovat jejich odbornou správnost na jedné straně a kvalitní didaktické ztvárnění na straně druhé.

Kromě výše uvedené aktualizace kurikula má řešení dynamických míst $\mathrm{z}$ našeho pohledu př́nos také $s$ ohledem na řešení míst kritických. $V$ rámci studie jsme uvedli dva př́klady ztvárnění dynamických míst kurikula fyziky a zeměpisu. V obou případech se ukázalo, že ztvárnění dynamických míst má potenciál pomoci $s$ překlenutím zjištěných kritických míst kurikula. Ve fyzice se jedná o kritické místo Magnetické pole a indukční čáry, $\mathrm{k}$ jehož překlenutí může pomoci vzdělávací program nabízený Pevností poznání v Olomouci zaměřený na magnetickou kapalinu a nanotechnologie (Kohout et al., 2019a). V případě zeměpisu může vzdělávací program Moderní kartografie a GPS vytvořený science centrem iQLANDIA 
v Liberci pomoci s překonáním kritičnosti témat Orientace na mapě a Práce s mapou (Pluháčková et al., 2019). Ukazuje se, že pro další výzkum dynamických míst je žá- doucí věnovat pozornost také jejich kritičnosti. K tomuto účelu se jeví jako vhodný zejména model didaktické rekonstrukce (Knecht, 2007, 2017).

\section{LiteratURA}

Auger, P. 1961. Current trends in scientific research: Survey of the main trends of inquiry in the field of the natural sciences, the dissemination of scientific knowledge and the application of such knowledge for peaceful ends. UNESCO.

Bencze, L., \& Hodson, D. 1999. Changing practice by changing practice: Toward more authentic science and science curriculum development. Journal of Research in Science Teaching, 36, 521-539.

Cloutier, R., Dwyer, J., \& Sherrod, S. 2016. Exploration of hands-on/minds-on learning in an active STEM outreach program. ASEE $123^{\text {rd }}$ Annual Conference \& Exposition. New Orleans, LA (Paper ID \#16121).

Durrani, M., \& Rodgers, P. 1999. Physics: past, present, future. Physics World, 12, 7-14.

Glänzel, W. 2003. Bibliometrics as a research field: A course on theory and application of bibliometric indicators. Course Handouts.

Gurnell, A. 2018. Twenty-five years of progress in physical geography: A personal view of its antecedents and trajectory. Geography, 103(3), 122-136.

Hajerová Műllerová, L., \& Slavík, J. 2020. Modelování kurikula. Plzeň: Západočeská univerzita. Hawley, D., \& Lyon, J. 2017. Plate update: Refreshing ideas for teaching plate tectonics. Teaching Geography, 42(1), 30-32.

Janík, T., Maňák, J., \& Knecht, P. 2009. Cile a obsahy školniho vzdèlávání a metodologie jejich utváreni. Brno: Paido.

Janík, T., Slavík, J., Mužík, V., Trna, J., Janko, T., Lokajičková, V., ... Zlatníček, P. 2013. Kvalita (ve) vzděláváni: obsahově zaměrený prìstup ke zkoumáni a zlepšováni výuky. Brno: Masarykova univerzita.

Janík, T. 2018. Od obsahu vzdělávání k žákově znalosti: kritická místa na cestě do školy a ze školy. Arnica, 8(1), 1-8.

Jelemenská, P., Sander, E., \& Kattmann, U. 2003. Model didaktickej rekonštrukcie: Impulz pre výzkum v oborových didaktikách. Pedagogika, 53(2), 190-201

Kattmann, U. 2009. Didaktická rekonstrukce: učitelské vzdělávání a reflexe výuky. In: T. Janík a kol. Možnosti rozvíjení didaktických znalostí obsahu u budoucích učitelù (s. 17-32). Brno: Paido.

Klafki, W. 1995. Zum Problem der Inhalte des Lehrens und Lernens in der Schule aus der Sicht kritisch-konstruktiver Didaktik. In S. Hopmann \& K. Riquarts (Eds), Didaktik undl oder Curriculum. Grundprobleme einer international vergleichenden Didaktik (s. 91-102). Weinheim u.a.: Beltz. 
Knecht, P. 2007. Didaktická transformace aneb od „didaktického zjednodušení “ k „didaktické rekonstrukci. Orbis Scholae, 2(1), 67-81.

Knecht, P. 2017. Model didaktické rekonstrukce. In J. Slavík a kol. Transdisciplinární didaktika: o učitelském sdilení znalostí a zvyšování kvality výuky napríč obory (s. 268275). Brno: Masarykova univerzita.

Kohout, J., Masopust, P., Mollerová, M. et al. 2019a. Kritická mista kurikula fyziky na 2. stupni základni školy I. Plzeň: Západočeská univerzita.

Kohout, J., Mollerová, M., Masopust, P., Feřt, L., \& Slavík, J. 2019b. Kritická místa kurikula na základní škole pohledem mezinárodního šetření TIMSS a českých učitelů - poznatky z fyziky. Pedagogická orientace, 29(1), 5-42.

Kohoutek, R., \& Řehulka E. 2011. Stresory učitelů základních a středních škol v České republice (zejména stresory způsobené žáky). In E. Řehulka (Ed.), Škola a zdraví pro 21. století (s. 105-117). Brno: Masarykova univerzita.

Kolářová L., \& Rálišová E. 2017 The concepts of nanotechnology as a part of physics education in high school and in interactive science museum. (Online). AIP Conference Proceedings 1804, 040005

Krninský, L. 2012. Pracovní zátěž a stres v povolání učitele (přehledová studie). e-Pedagogium, 12(1), 82-108.

Maňák, J., Janík, T., \& Švec, V. 2008. Kurikulum v současné škole. Brno: Paido.

Mentlík, P. 2016. Srovnání dynamiky vědeckých výstupů mezi geografickými obory v ČR (2012 až 2014) pro potřeby cílené didaktické transformace. Arnica, 5(1-2), 1-11.

Mentlík, P., Slavík, J., \& Coufalová, J. 2018. Kritická místa kurikula, organizační a klíčové koncepty - konceptuální vymezení a př́klady z výuky geověd, Arnica, 8(1), 9-18.

MŠMT. 2017. Rámcový vzdélávaci program pro základni vzdělávání. Dostupné z: www.nuv.cz Pluháčková, M. 2018. Deglaciace v Západnich Tatrách a jeji vazba na gravitačni deformace rïzných typů s didaktickou transformaci sledovaných jevi a zjištěných výsledkü. Disertační práce. Př́rodovědecká fakulta, Ostravská univerzita.

Pluháčková, M., Duffek, V., Stacke, V., \& Mentlík, P. 2019. Kritická mista kurikula zeměpisu na 2. stupni základni školy I. Plzeň: Západočeská univerzita.

Rendl, M., \& Vondrová, N. 2014. Kritická místa v matematice u českých žáků na základě výsledků šetření TIMSS 2007. Pedagogická orientace, 24(1), 22-57.

Slavík, J., Janík, T., Najvar, P., \& Knecht, P. 2017. Transdisciplinární didaktika. Brno: Masarykova univerzita.

Vamvakeros, X., Pavlatou, E. A., \& Spyrellis, N. 2010. Survey exploring views of scientists on current trends in chemistry education. Science \& Education, 19(2), 119-145.

Van Noorden, R., Maher, B., \& Nuzzo, R. 2014. The top 100 papers: nature explores the most-cited research of all time. Nature, 514(7524), 550-553.

VÚP. 2007. Rámcový vzdělávaci program pro gymnázia. Dostupné z: www.nuv.cz 
Mgr. Markéta Kuberská, Ph.D.,

Západočeská univerzita v Plzni, Fakulta pedagogická, Centrum biologie, geovéd a envigogiky;

e-mail:pluhym@cbg.zcu.cz

PhDr. Pavel Masopust, Ph.D.,

Západočeská univerzita v Plzni, Fakulta pedagogická, Katedra matematiky, fyziky a technické výchovy; e-mail:pmasop@kmt.zcu.cz

Mgr. Lucie Kolárová,

Univerzita Palackého v Olomouci, Prírodovédecká fakulta, Katedra experimentálni fyziky;

e-mail: lucie.kolarova@upol.cz

Mgr. Petr Desenský,

iQLANDIA, Programový úsek;

e-mail: desensky@iqlandia.cz

doc. PaedDr. Jan Slavik, CSc.,

Západočeská univerzita v Plzni, Fakulta pedagogická, Katedra výtvarné výchovy a kultury;

e-mail: slavikj@kvk.zcu.cz

doc. RNDr. Pavel Mentlik, Ph.D.,

Západočeská univerzita v Plzni, Fakulta pedagogická, Centrum biologie, geovèd a envigogiky;

e-mail:pment@cbg.zcu.cz

\section{KUBERSKÁ, M., MASOPUST, P., KOLÁŘOVÁ, L., DESENSKÝ, P., SLAVÍK, J., MENTLÍK, P. Dynamic Areas of Curricula as a Bridge be- tween Formal and Non-Formal Education}

The aim of this theoretical-methodological study is to define the construct of dynamic areas of curricula, to contextualize it, to describe the research methods of the construct, and to present examples of good practice. The term 'dynamic area' is defined and put into the context of established constructs such as content transformation or the modernization of curricula in the first part of the paper. The role of formal and non-formal education in the process of transformation is discussed in the same part of the paper. The second part deals with research methods for the specification of dynamic areas of disciplines and methods dealing with the selection and legitimization of the dynamic areas for content transformation. The last part focuses on the presentation of examples of good practice. Two suggestions as to how to present selected dynamic areas of geography and physics 
curricula are described here. The dynamic areas of the curricula are presented as a potential connection between formal and non-formal education in this study. The first reason for this is because of the advantages of cooperation between providers of formal (lecturers and teachers) and non-formal (for example, science centre staff) education in the process of the specification and selection of the dynamic areas of the disciplines. The second reason is the significant potential of non-formal education institutions for the presentation of selected dynamic areas because of their well-equipped expositions and laboratories. It should be possible to innovate the curricula of formal education through educational programmes offered by non-formal education institutions to schools.

Keywords: dynamic areas of disciplines, dynamic areas of curricula, curricular innovation, content transformation, non-formal education, science centres 